Pamukkale University Journal of Social Sciences Institute

Article Info/Makale Bilgisi
VReceived/Geliş:09.06.2021 VAccepted/Kabul:19.07.2021
Doi: 10.30794/pausbed.950254
Araştırma Makalesi/ Research Article

Ozer, E. ve Ay, Ü. (2022). "The Effects of Technology Management Capability and Strategy Typology on Firm Performance: A Review in The Manufacturing Sector", Pamukkale Üniversitesi Sosyal Bilimler Enstitüsü Dergisi, Sayı 48, Denizli, ss. 123-138.

\title{
THE EFFECTS OF TECHNOLOGY MANAGEMENT CAPABILITY AND STRATEGY TYPOLOGY ON FIRM PERFORMANCE: A REVIEW IN THE MANUFACTURING SECTOR
}

\author{
Elife OZER*, Ünal AY**
}

\begin{abstract}
Despite its growing importance in the management field, a limited number of studies have empirically investigated technology management capabilities with strategies in the environmental adaptation context. In rapidly changing environmental conditions, companies need to develop technological skills to achieve a competitive advantage. As a dynamic capability, the development of technological capabilities requires allocating resources consistent with strategic goals. The present study, therefore, aims to examine how technology management capability and strategy type affect firm performance. Miles and Snow's strategy typology was used to classify firms' strategies. The results are drawn from a survey of 119 Turkish manufacturing companies. The research results contribute to the literature with empirical support on a significant effect of the technology management capability and strategy type on firm performance. Besides, the findings show a significant positive relationship between technology management capability and strategy types.
\end{abstract}

Keywords: Technology management, Technology management capability, Strategy typology, Firm performance.

\section{TEKNOLOJI YÖNETIMI YETENEĞi VE STRATEJi TIPININ FIRMA PERFORMANSINA ETKISI: IMALAT SEKTÖRÜNDE BIR INCELEME}

Öz

Yönetim alanındaki artan önemine rağmen, sınırlı sayıda çalışmanın, çevresel adaptasyon bağlamında teknoloji yönetimi yeteneklerini stratejilerle birlikte ampirik olarak araştırdığı görülmektedir. Hızla değişen çevre koşullarında şirketlerin rekabet avantajı elde edebilmeleri için teknolojik beceriler geliştirmeleri gerekmektedir. Dinamik bir yetenek olarak, teknolojik yeteneklerin geliştirilmesi, kaynakların stratejik hedeflerle tutarlı bir şekilde tahsis edilmesini gerektirir. Bu nedenle bu çalışma, teknoloji yönetimi yeteneğinin ve strateji tercihinin firma performansını nasıl etkilediğini incelemeyi amaçlamaktadır. Teknoloji yönetimi yeteneği, bir firmanın bir dizi faaliyeti gerçekleştirme düzeyi bağlamında ölçülmüştür. Firmaların stratejilerini sınıflandırmak için ise Miles ve Snow'un strateji tipolojisi kullanılmıştı. Adana ve Mersin'de faaliyet gösteren 119 imalat firmasından toplanan anket verilerine dayanan bulgular, teknoloji yönetimi yeteneğinin ve strateji tipinin firma performansı üzerindeki anlamlı etkisi konusunda ampirik destekle literatüre katkıda bulunmaktadır. Ayrıca bulgular, teknoloji yönetimi yeteneği ile strateji tipleri arasında anlamlı bir pozitif ilişki olduğunu göstermektedir

Anahtar Kelimeler: Teknoloji yönetimi, Teknoloji yönetimi yeteneği, Strateji tipi, Firma performansı.

*PhD, Adana Alparslan Turkes Science and Technology University, Faculty of Business, Management Information Systems Department, ADANA.

e-posta: efyilmaz@atu.edu.tr, (https://orcid.org/0000-0002-5834-7483)

** Prof. Dr., Cag University, Faculty of Economics and Administrative Sciences, International Management Department, MERSiN. e-posta: unalay@cag.edu.tr, (https://orcid.org/0000-0002-5924-104X) 


\section{Pamukkale Üniversitesi Sosyal Bilimler Enstitüsü Dergisi, Sayı 48, Ocak 2022 E. Ozer, Ü. Ay}

\section{INTRODUCTION}

Companies must adapt to environmental change in order to be successful in todays' global competition. Especially when the environment is hard to predict and dynamic, reviewing organizational routines (March, 1991) and developing change-oriented capabilities become imperative for firms. In this context, dynamic capabilities are considered an important concept and their impact on firm performance and competitive advantage is being emphasized in several studies (For example, Teece, 2007; Ferreira, Coelho \& Moutinho, 2020; Lin and Lai, 2020). Teece, Pisano and Shuen (1997: 516) defined dynamic capabilities as a firm's "ability to create, reconfigure and integrate internal and external competencies to respond to rapidly changing environmental conditions". As technology is developing and changing at a fast pace and Teece (2007) suggested that dynamic capabilities enable firms to gain a competitive advantage in a rapidly changing environment points to the development of technological capabilities. Hence, managing technology within a framework of a system in organizations is considered as a dynamic capability (Çetindamar, Phaal and Probert, 2009).

Several researchers (Gupta, Chen and Chiang, 1997; Pelser and Prinsloo, 2014; Nazeer, Rasiah and Furuoka, 2021) have stressed the importance of technological capabilities in firms' competitive advantage. Technology capabilities represent an important driver of strategies and therefore effective use of technology can result in efficient production and delivery of goods and services (Parnell and Brady, 2019). The level and efficiency of firm technology management determine firms' competitive position and performance (Zahra, 1996). Therefore, some firms have added technology management goals in their strategic plan and allocate some of their scare resources to deploying technology in their work process and to gain a competitive advantage (McCann, 1991). However, there is a need for further empirical studies because the empirical findings on the impact of technology management on firm performance are not constant (Zahra, 1995; Bharadwaj, 2000). For example, Zahra (1995) observes that the relation between independent ventures' technology management and their performance was significantly higher than the corporate ventures' technology management and performance. When researchers add other factors in their analysis, their findings became much more complex (Gibbons and O'Connor, 2003). Therefore, it is insisted that the firm technology management and performance relation should not be analysed without considerations of the other external and internal factors (Zahra and Covin, 1995) such as firm strategies. On the other hand, the literature -except Dvir, Segev, and Shenhar (1993)- neglects to explore such multiple relations. Firms' competitive strategies should be added when analysing such a relation since firms first determine their competitive strategies. Based on this literature, the current study aims to explore the relationship between firm technology management capability and performance along with firms' strategy preferences. Based on the compatibility of the adaptation cycle structure with dynamic capabilities theory, which suggests developing strategies according to changing environmental conditions, Miles and Snow's (1978) framework was examined as a strategy classification.

The study intents to contribute to the literature with empirical evidence derived from the field study and the incremental adjustments made in the measurement tools, along with recommendations made to firms based on the results.

\section{LITERATURE REVIEW}

Firm performance can be defined as the time test of any strategy (Schendel and Hofer, 1979) and the improvement of firm performance is stated at the very heart of strategic management. Regarding the determinants of firm performance, there are two major trends in the literature; one is based on economic model that emphasises the importance of market factors in determining firm success and the second one is organizational model that takes account of organizational factors and their fit with the environment (Hansen and Wernerfelt, 1989). In the strategy studies, it can be measured using either the financial indicators such as sales growth, profitability, earnings per share and so on or operational indicators such measures as market-share, new product introduction, product quality and other measures of technological efficiency or both (Venkatraman and Ramanujam, 1986).

One of the several studies supporting a positive relation between technological capabilities and firm performance is Unsal and Cetindamar's (2015) empirical study. They found a positive influence of technology 


\section{Pamukkale Üniversitesi Sosyal Bilimler Enstitüsü Dergisi, Sayı 48, Ocak 2022 E. Ozer, Ü. Ay}

management activities on competitive advantage and resulting a higher firm performance. National Research Council's report states that managing technology well is an important key for business success (NRC, 1987: 9, 16). Gillespie and Mileti's (1977: 7) study also suggests that technology is a significant variable in measuring variance in firm performance.

Gregory (1995) defines the key technology management activities as; identification of technological options, selection of technologies that should be supported by the firm, acquisition of the selected technologies, exploitation of them to generate profit or to achieve organizational goals, protection of knowledge and knowhow embedded in products and manufacturing systems (Cetindamar, Phaal, and Probert, 2009). Rush, Bessant and Hobday (2007) added learning to these activities which assumed to be a critical part of technological competency. Morrison's (2020) recent study also confirms the key technology management activities -except the protection- in daily work activities across different manufacturing industries in the central America. In addition to these core activities knowledge management, project management, innovation management and strategic management are proposed as supporting activities (Cetindamar et al., 2009; Unsal and Cetindamar, 2015). These concepts have so far been considered inseparable from technology management (Gudanowska, 2017) and the main activities should not be evaluated without them. Being able to accomplish aforementioned activities on a routine and system basis will provide companies develop technology management capability, which can be a competitive advantage.

A competitive strategy is described by Porter (1980) as a broad formula for how a business is going to compete, what its goals and policies will be needed to carry out. In order to gain a competitive advantage, two dominant perspectives are recognised in the literature; industrial organization view suggests that external sources as the industry are the determinants of the sustainable competitive advantages (Porter, 1980) whereas; resourced-based view focuses on the internal sources and competencies of firms (Wernerfelt, 1984). Snow and Hrebiniak (1980) argue that firms are recognized as having distinctive competence that differentiates them from their competitors and an organization performs well if it possesses distinctive capabilities. The authors also suggest firm strategy must be supported with relevant distinctive capabilities in order to achieve high firm performance. Since technological capability is seen as a distinctive capability (defined as a dynamic capability, Cetindamar et. al., 2009), examining its effect on firm performance along with firms' competitive strategy can produce meaningful results.

Organizations develop adaptation strategies based on their perceptions of the environment. Miles and Snow (1978) argue that the strategies that associate the strategies, structures and processes of organizations (Conant et al., 1990: 366), which they define as adaptation cycles, are similar to the strategies developed while solving the entrepreneurship, engineering and managerial problems. In Miles and Snow's strategy typology framework, organizations are classified according to the strategies they implement to solve these three problems. First, three types of strategy are defender, analyser and prospector strategies. Each type has distinctive strategies for its own market, technology, structure and processes. Whereas reactive strategies, which are defined as a failure rather than a consistent strategy, are also considered as the fourth group (Miles, Snow, Meyer and Coleman, 1978: 548).

Miles and Snow's (1978) four strategy types have been examined within the scope of the strategy that organizations use in their environmental adaptation processes, focusing on the harmony of organizational structure, strategies and processes, and defending that organizations will achieve a superior performance by applying appropriate strategies in accordance with their capabilities. Along with the aforementioned literature, Zahra and Covin's (1995) emphasize on the need for fit between firm strategy and the technological choices to help reach the goals of their business strategies, supported the study's direction.

\section{METHODOLOGY}

\subsection{Research Objectives and Hypothesis}

The aim of this study is to analyse the impact of the technology management activities and firm strategies on firm performance. In the light of the literature, it is proposed that technological capabilities will be developed 
more effectively with harmonious strategies. In this context, Miles and Snow's (1978) strategy typology was predicted to have a meaningful relationship with technology management capability. Therefore, the research model proposed to analyse with empirical data is presented in Figure 1.

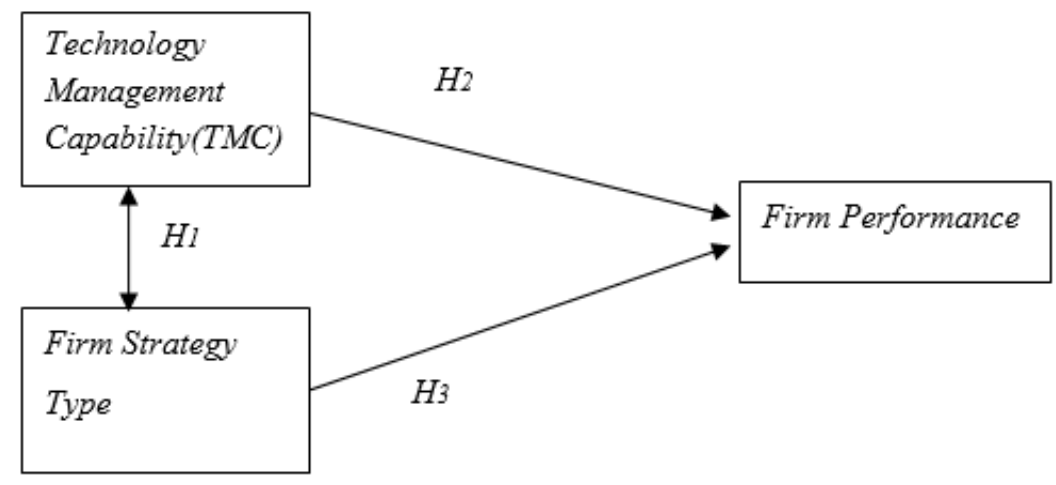

Figure 1: Proposed Research Model

The first hypothesis was developed upon the relationship of TMC and firm strategy type. Because the analysers strive to balance flexibility and stability and, make cautious investments on the basic technologies in this direction. Their focus on efficiency and productivity reinforces the idea that those companies may have developed effective processes related to the management of technology. Besides this, the prospector strategytype firms with strong innovation focus, investments would be made in order to improve the technological capabilities. Regarding such relationships between strategy type and technology management capability presumed, $\mathrm{H} 1$ hypothesis is proposed.

$H_{1}$ : There is a significant relationship between technology management capability and the strategy type.

In addition to the direct or indirect positive effects of TMC-dynamic capabilities on the competitive advantage of firms in different sectors, there are also studies advocating that such an effect does not exist (Bharadwaj, 2000). The claim that TMC will have a significant effect on firm performance is stated as the second hypothesis for empirical testing.

$\mathrm{H}_{2}$ : Technology management capability has a significant effect on firm performance.

The last hypothesis of the research is stated as follows in line with the studies conducted in different sectors that the performances of different strategy types will show a significant difference.

$\mathrm{H}_{3}$ : There is a significant difference in firm performance according to the strategy type.

\subsection{Sample and Data Collection}

The data was collected through a questionnaire from a sample of manufacturing companies operating in Adana and Mersin, two major cities in the south region of Turkey. The cities have a great potential in terms of production factors and receive investments from both the government and private sector. Data collection procedure was initiated with a list of firms obtained from the chambers of industry. The number of registered companies was 2368. However, with the consultancy from the chambers of industry, companies without any commercial activity were excluded from the list and the sampling frame consisted of 1956 firms.

The first draft of the questionnaire was pre-tested in January 2016 with four managers at manufacturing firms and 30 MBA students who were owners or managers of small and medium size companies in the region. The results of pre-test showed that some items had double meaning or not clear. Based on participants' comments, small adjustments were made in the items of the scales. 
The unit of analysis is the firm and each questionnaire represents a company. The questionnaire form was conducted as self-administered. Data collection was carried out between December 2016 and March 2017. A notable support was received from chambers of industry in the field work in terms of recommendations and reaching the firms in the sample.

In concern with reducing common method bias, statements were tried to eliminate ambiguity followed by the pre-test, personal information was included as little as possible and placed at the end of the survey, and respondents were informed about the study before filling the questionnaire. In order to increase the participation, managers were phoned to inform about the study, face-to-face interviews were conducted with the managers who accepted, the questionnaire (including the online questionnaire link) was sent via e-mail upon request. Participation in the meetings of the industry chambers, involving in a fieldwork of the Adana chamber of industry and an extra support from a professional survey company (www.ikonarastirma.com) also contributed to the data collection. As a result, 200 companies were contacted and 136 returns were received (with 68\% rate of return) but 17 data were considered invalid due to missing important information.

Consequently, the results are based on 119 valid questionnaire data obtained from manufacturing companies. $41 \%$ of those who participated in the study were senior managers, $30 \%$ were mid-level managers and $29 \%$ were experienced specialists representing their companies.

\subsection{Scales}

The scales of each variable were exploited from previous studies. Technology management capability scale was adopted from Unsal (2010), Strategy typology items were instrumented from Conant, Mokwa and Varadarajan's (1990) study. Finally, perceived firm performance items are inspired from various strategy studies (Tippins and Sohi, 2003; Wu, Yeniyurt, Kim, and Cavusgil, 2006; Xiao and Dasgupta, 2009).

\section{Technology Management Capability (TMC)}

In this study, technology management is considered as a process. The implementation frequency of the defined technology management activities is evaluated as the technology management capability. The original TMC scale used in the study had consisted of 27 items to evaluate two basic (main and supporting activities) and 10 sub-dimensions. The 5-point Likert type scale designed to measure the frequency of the given technology management activities by response options: "never", "rarely", "indecisive", "mostly" "always". Based on the literature and information obtained during the pre-test process, 12 new items were added to the scale.

\section{Strategy Typology}

The strategy type classification of Miles and Snow (1978) is measured by different methods such as multiplechoice questions, paragraph definition, and decision-making based on real data (for further information; Snow and Hrebiniak, 1980; Segev, 1987; Hambrick, 1983; Meyer, 1982). In the present study, the strategy typology scale developed by Conant et al. (1990) was adopted. This scale originally consists of 11 questions and four multiple choice items representing each strategy type. Inspired by the Gnjidic's (2014) study, the level of measurement of the scale was slightly revised. Aiming to make the scale semi-numerical, questions responses were arranged in a 5-point grading style with a multiple selection procedure. Thus, the original scale designed as nominal level of measurement, had maximum of 11 points. After the new arrangement, the highest value that can be obtained for each strategy class has been increased to 55 points. In this way, the researchers aimed to increase the measurement level of the scale. The response options are 5-point Likert grading type designed as "very little valid", "somewhat valid", "moderately valid", "mostly valid" and "fully valid".

In order to assign the companies to the strategy categories, the average of the responses given for each strategy type were evaluated. According to Conant et al. (1990: 376) the average scores obtained out of five, in the case of the average score of a strategy type is at least 2.73 (representing $54.5 \%$ of the total score) and the highest scored category is assigned as the related strategy class. In case of obtaining the same or very close level in more than one strategy type, the firm is classified as 'analyser' when 'prospector, 'defender' and 'analyser' strategy responses are very close to each other. If the average of reactor strategy type responses approaches 
any strategy type score, the company is classified as reactor (referring to Miles and Snow, 1978 and Conant et al. 1990: 373). That is because reactors have been presented as an 'inconsistent' type lacking a consistent strategy.

\section{Firm Performance}

Firm performance was measured by a subjective evaluation through nine financial and non-financial variables. Due to the general inconvenience of firms, such as difficulties encountered in collecting many sensitive data, such as profitability, return on investments and so on (Tippins and Sohi, 2003: 753), subjective performance assessment is widely applied in the strategic management field (For example; Dess, 1987; Conant et al., 1990; Powel, 1992; Powell and Dent-Micallef, 1997; Spanos and Lioukas, 2001).

In this study, managers were asked how the 'profitability rate', 'increase in sales', 'market share', 'profitability in investments', 'customers satisfaction', 'contribution of new products to sales', 'R\&D investments', 'production flexibility' and 'advanced technology practices in production' was compared to 3 years ago. The response options are 5-point Likert type designed as "much lower", "lower", "same", "higher" and "much higher". Conant et al. (1990: 375) also adopted a similar application.

\section{RESULTS AND DISCUSSION}

The reliability of the scales was tested by the Cronbach's Alpha coefficient (Price, 1997: 308). Although the strategy typology scale has a nominal level of measurement, the items that make up the classes were designed as 5-point Likert type and therefore it was subject to reliability analysis. One item from the firm performance and 10 items from the TMC scale were deleted based on the findings of exploratory factor analysis. The Cronbach's Alpha scores are given in both cases in the Table 1.

Table 1: Cronbach's Alpha coefficients of the scales

\begin{tabular}{|l|l|l|}
\hline Scale & Number of items & Cronbach's Alpha \\
\hline TMC & 39 & .96 \\
\hline Strategy Type & 44 & .95 \\
\hline Firm Performance & 9 & .84 \\
\hline Values obtained after item extraction & \multicolumn{2}{|l|}{} \\
\hline Scale & Number of items & Cronbach's Alpha \\
\hline TMC & 29 & .94 \\
\hline Firm Performance & 8 & .83 \\
$n=119$ & &
\end{tabular}

The test of normality was analysed by examining the skewness, kurtosis values and Kolmogorov-Smirnov test. The skewness values for TMC ranged from -1.351 to .238; kurtosis values range from -1.322 to 2.377. KolmogorovSmirnov test also confirmed the similarity of TMC data to normal distribution ( $p=.427>.05$; Kolmogorov-Smirnov $Z=.876$ ). For the firm performance, the skewness values were between - .886 and - .085; The kurtosis values were observed between -1.028 and 1.128 , and Kolmogorov-Smirnov test confirmed the similarity of the data to normal distribution $(p=.453>.05 ; Z=.858)$.

\subsection{Descriptive Statistics}

Descriptive characteristics such as sub-sectors, company foundation year, and number of employees are presented in the Table 2. 
Pamukkale Üniversitesi Sosyal Bilimler Enstitüsü Dergisi, Sayı 48, Ocak 2022 E. Ozer, Ü. Ay

Table 2: Descriptive characteristics of the firms in the sample

\begin{tabular}{|l|c|c|l|c|c|}
\hline Capital structure & $\mathrm{n}$ & $\%$ & Sub-sectors & $\mathrm{n}$ & $\%$ \\
\hline & & & Food & 22 & 18,3 \\
\hline Domestic & 100 & 83,3 & Textile & 21 & 17,5 \\
\hline $\begin{array}{l}\text { Domestic and Foreign } \\
\text { partnership }\end{array}$ & 8 & 6,7 & Fabricated Metal Products & 17 & 14,2 \\
\hline Foreign & 6 & 5 & Rubber and Plastic & 13 & 10,8 \\
\hline & & & Chemicals & 11 & 9,2 \\
\hline Company Age & 22 & 19 & Construction Materials & 6 & 5 \\
\hline $3-10$ years & 27 & 23 & $\begin{array}{l}\text { Machinery and Equipment Not } \\
\text { Classified Elsewhere }\end{array}$ & 4 & 3,3 \\
\hline 11-20 years & 26 & 22 & Paper, Packaging and Printing & 4 & 3,3 \\
\hline $21-30$ years & 17 & 15 & Wood Products & 4 & 3,3 \\
\hline $31-40$ years & 17 & 15 & Land vehicles & 4 & 3,3 \\
\hline $41-50$ years & 8 & 7 & Main Metal & 3 & 2,5 \\
\hline $51-87$ years & & & $\begin{array}{l}\text { Electricity, Automation and } \\
\text { Energy }\end{array}$ & 3 & 2,5 \\
\hline & & Others & 2 & 1,7 \\
\hline
\end{tabular}

While the vast majority (83\%) of the companies in the sample were domestic companies, six companies did not respond the question. The youngest of the company in the sample was founded in 2014 and the longest was in 1930 (three companies did not respond it). The mean age of the firms' is 26 years (s.d. = 16). The proportion of companies that have been operating for less than 10 years, which can be described as young, was about $19 \%$ and $7 \%$ of the companies have been in operation for more than 50 years.

The companies participating in the survey were from 13 different sub-sectors. Sectoral grouping was made based on the classifications of the chambers of industry. Two companies under the "Other" category were the companies that prefer to keep their sectoral information confidential. When taken proportionally, three sectorsfood, textile and fabricated metal products, make up to $50 \%$ of the sample.

Firms' size was classified based on the number of employees. The smallest firm in the sample has four employees whereas the largest firm has 3000 employees (Table 3).

Table 3: Firm size information of sample

\begin{tabular}{|l|l|l|l|}
\hline Number of employees & Firm's scale & $\mathrm{n}$ & $\%$ \\
\hline$<50$ & Small & 36 & 30 \\
\hline $50<x<250$ & Medium & 39 & 33 \\
\hline$>250$ & Large & 25 & 21 \\
\hline
\end{tabular}

\subsection{Factor Analysis Results}

\subsubsection{TMC Scale}

TMC scale, which is one of the independent variables of the study, originally consisted of 27 items, and 12 items were added. Exploratory factor analysis was used to measure the relationship and structural consistency of the items with the TMC scale. As given in Table 4, Bartlett's test was significant for TMC $(p=.00<.05)$. This value shows that there is a sufficient correlation between the items to continue factor analysis (Hair, Black, Babin, Anderson and Tatham, 2014: 103). The KMO test, which is another criterion that indicates the suitability of the data set for factor analysis, calculated as .86. 
Pamukkale Üniversitesi Sosyal Bilimler Enstitüsü Dergisi, Sayı 48, Ocak 2022 E. Ozer, Ü. Ay

Table 4: Factor Analysis findings of the TMC scale

\begin{tabular}{l|l|}
\hline Test Statistics & Value \\
\hline Bartlett's Sphericity Test & $\mathrm{p}=.00$ \\
\hline KMO Sample Validity Criterion & .86 \\
\hline$p<.05$ & \\
\hline
\end{tabular}

Eigenvalues and Varimax rotation methods were used in determining the number of factors. Considering the communality values for the lowest acceptable explanations of the variables, it was found that the value of each variable is over .50. For the TMC scale, nine factors with an eigenvalue greater than 1 were identified and these factors explained $72.55 \%$ of the total variance. While the first factor explained a very large part of this rate (40\%), other factors explained between $6 \%$ and $2.5 \%$ of the variance.

Table 5: TMC Exploratory factor analysis -Total variance explained

\begin{tabular}{|l|c|c|}
\hline Factors & Variance \% & Cumulative Variance \% \\
\hline 1 & 40.39 & 40.39 \\
\hline 2 & 6.88 & 47.27 \\
\hline 3 & 5.41 & 52.67 \\
\hline 4 & 4.26 & 56.94 \\
\hline 5 & 3.67 & 60.60 \\
\hline 6 & 3.42 & 64.03 \\
\hline 7 & 3.03 & 67.06 \\
\hline 8 & 2.90 & 69.96 \\
\hline 9 & 2.59 & 72.55 \\
\hline
\end{tabular}

$\mathrm{n}=119$

The distribution of the items to the factors differed from the original scale, but this is an expected result since the sample size, sectors and region were different from original scale's implementation. When the factor loads of the newly added items were analysed, "Market analysis is done for production technologies" item added to the definition dimension loaded with close values under .40, in factors 1, 3 and 7. Hair et al. (2014: 117) argues that if a variable takes significant load on more than one factor in different rotation methods, the possibility of deletion should be considered. Referring to this proposal, the statement was removed. In the same concern, 10 items decided to be extracted from the scale and 6 of the 12 newly added items were kept. In addition to reliability analysis applied to the whole scale, this judgment has been made as a result of factor analysis repeated many times with the removal of all newly added items as well as removal and addition of individual and specific items.

In the factor analysis performed after item extraction, Bartlett's Sphericity test was significant $(p=.00<.05)$ and the KMO sample validity criterion was calculated as .86. Common variance values were between .54 and .80 . In the last case, a structure with seven factors was formed and these factors explained $70.36 \%$ of the variance in TMC.

As a result of the empirical study carried out within the scope of the research, a new structure is proposed by deleting four items from the acquisition, commercialization and innovation management dimensions and keeping six of the new items in the scale. However, the TMC scale was evaluated as a whole in the analysis of the present study. There was no further analysis conducted on the factor level.

\subsubsection{Firm Performance Factor Analysis Results}

According to the results of the exploratory factor analysis of the perceived firm performance items, Bartlett's test was significant $(p=.00<.05)$ and KMO sample validity value was calculated as $76 \%$. These values support the suitability of the data for factor analysis. When the communalities of the variables were analysed, there were two variables with values below .50: customer satisfaction and the contribution of new products to sales. Based 
on the results of the factor analysis, the 'customer satisfaction' item was removed from the scale. The variances explained by the factors resulting from this result and the factor loads of the variables are presented in Table 6 .

Table 6: Firm performance factor analysis results after subtraction

\begin{tabular}{|c|c|c|}
\hline Items & $\begin{array}{c}\text { Factor } 1 \\
\text { Variance Explained: } \\
46.93 \%\end{array}$ & $\begin{array}{c}\text { Factor } 2 \\
\text { Variance Explained: } \\
16.03 \%\end{array}$ \\
\hline Profitability & .841 & \\
\hline Growth in sales & .824 & \\
\hline Return on investment & .799 & \\
\hline Market share & .775 & \\
\hline Using advanced technology in production & & .781 \\
\hline R\&D Investments & & .748 \\
\hline Production Flexibility & & .725 \\
\hline Contribution of new products to sales & & .593 \\
\hline Total variance explained: $\quad 62.9 \%$ & & \\
\hline
\end{tabular}

\subsubsection{Strategy Type Scale Findings}

The basis of the decision rules was determined by Miles and Snow (1978). Analysers are essentially hybrid organizations with the characteristics of prospector and defender strategies. Reactors respond inconsistently to the opportunities and threats of the adaptation cycle. For example, they can act as defenders when managing environmental regulations, as prospectors when producing new products, and as an analyser when evaluating performance. The decision structure based on this way also prevents the loss of important data (Conant et al., 1990, 373). Strategy type findings are represented in Table 7.

Table 7: Firms' strategy type findings

\begin{tabular}{|l|c|c|}
\hline Strategy Type & $\mathbf{n}$ & \% \\
\hline Prospector & 8 & 6.7 \\
\hline Defender & 14 & 11.8 \\
\hline Analyser & 36 & 30.3 \\
\hline Reactor & 61 & 51.3 \\
\hline Total & 119 & 100 \\
\hline
\end{tabular}

61 per cent of the companies participating in the study were included in the reactor strategy group. As Miles and Snow (1978) stated, it can be argued that the companies in question do not have a clear strategy structure. In the second rank, there were companies that fall into the analyser strategy category with $30 \%$. The number of firms defined as prospectors and defenders were relatively few.

\subsection{Hypotheses Tests}

\subsubsection{Strategy Type and TMC Relationship}

The ETA relation coefficient $(\eta)$ was used to examine the relationship between the strategy type and technology management capability of the companies, which is the first hypothesis of the study. Afterwards, One-way ANOVA analysis was conducted to examine whether TMC shows a significant difference according to the strategy type. ETA correlation coefficient is used for nonlinear relationships in cases where the dependent variable is qualitative (classification or ranking measurement level) and the independent variable is quantitative (ratio or proportional measurement level). 
Table 8: TMC and strategy type relationship

\begin{tabular}{|l|c|}
\hline Variables & Eta $(\eta)$ \\
\hline TMC & .424 \\
Strategy type & .424 \\
\hline
\end{tabular}

The ETA relationship coefficient $(\eta=.424)$ indicates that there is a significant $(p=.000<.05)$ and $42 \%$ positive relationship between strategy type and TMC.

One-way ANOVA was also performed to compare the TMC averages of the Prospectors, Defenders, Analysers and Reactors (Table 9). Levene's statistics showed that the variances were homogeneous ( $p=.567>.05$; Levene's $s=.678$; df1 = 3). In the one-way ANOVA, the difference between the group averages was found statistically significant $(F=8.388 ; p=.00<.05)$. This finding indicates that TMC differs significantly according to firm strategy type. As can be seen in Table 9, the highest TMC average belongs to the Analysers (3.93 \pm 0.509$)$ and the lowest TMC average was found for the firms implementing Defensive strategies $(3 \pm 0.659)$.

Table 9: Averages of TMC by Strategy Type

\begin{tabular}{|l|l|l|c|c|c|c|}
\hline & Group & $\mathrm{n}$ & Mean & Sd. & $\mathrm{F}$ & $\mathrm{p}$ \\
\hline \multirow{4}{*}{ Strategy Typology } & Prospector & 8 & 3.84 & .527 & & \\
\cline { 2 - 7 } & Defender & 14 & 3 & .659 & 8.388 & $.000^{*}$ \\
\cline { 2 - 7 } & Analyser & 36 & 3.93 & .509 & & \\
\cline { 2 - 7 } & Reactor & 61 & 3.77 & .641 & & \\
\hline
\end{tabular}

Complementary post-hoc analysis was conducted to identify the groups in which the difference originated, and the comparison of the Tukey HSD test was performed as the number of observations in the groups were not equal.

Table 10: TMC and strategy typology Tukey HSD test multiple comparison chart

\begin{tabular}{|l|l|c|c|c|}
\hline Strategy Type (i) & Strategy Type(j) & i-j & SH & p \\
\hline \multirow{4}{*}{ Prospector } & Defender & $\mathbf{0 . 8 3 0 6 5 *}$ & 0.26561 & .012 \\
& Analyser & -0.09921 & 0.23424 & .974 \\
& Reactor & 0.06971 & 0.22535 & .990 \\
\hline \multirow{3}{*}{ Defender } & Prospector & $-\mathbf{0 . 8 3 0 6 5 *}$ & 0.26561 & .012 \\
& Analyser & $-0.92986^{*}$ & 0.18876 & .000 \\
& Reactor & $-\mathbf{0 . 7 6 0 9 5 *}$ & 0.17760 & .000 \\
\hline \multirow{4}{*}{ Analyser } & Prospector & 0.09921 & 0.23424 & .974 \\
& Defender & $\mathbf{0 . 9 2 9 8 6 *}$ & 0.18876 & .000 \\
\hline \multirow{3}{*}{ Reactor } & Reactor & 0.16891 & 0.12595 & .539 \\
& Prospector & -0.06971 & 0.22535 & .990 \\
& Defender & $\mathbf{0 . 7 6 0 9 5 *}$ & 0.17760 & .000 \\
& Analyser & -0.16891 & 0.12595 & .539 \\
\hline
\end{tabular}

${ }^{*} p<.05$

Tukey HSD test (Table 10) shows that the difference stems from all groups compared to the defensive strategy. The average of the TMC level of the firms with Prospector, Analyser and Reactor strategies was higher than the firms in Defender strategy type.

As a result of the analysis, it was concluded that the $H 1$ hypothesis on a meaningful relationship between firm strategy type and technology management capability was supported. 


\subsubsection{TMC's Impact on Firm Performance}

Simple Linear Regression analysis was used to test the second hypothesis of the research, which proposed the effect of technology management capability on firm performance.

Table 11: Regression analysis findings regarding TMC and firm performance

\begin{tabular}{|l|l|l|l|l|c|}
\hline Model & Coefficients & & & & \\
\hline & B & Beta & T & p & $\mathrm{R}^{2}$ \\
\hline Constant & 1.916 & & 6.397 & .000 & .240 \\
\hline TMC & .480 & .490 & 6.078 & .000 & \\
\hline
\end{tabular}

As shown in Table 11, Beta coefficient was found as .490 and significant $(p=.000<.05)$. According to Evans (1996), there is a moderate positive relationship between the variables. Therefore, there is a moderately positive relationship between TMC and firm performance signifying that firm performance will increase as TMC level increases. The $\mathrm{R}^{2}$ value (.240) indicates that the $24 \%$ change in firm performance is explained by TMC, which is included in the model. In other words, $24 \%$ of the change in performance can be explained by the changes in TMC.

When the ANOVA table, which is one of the outputs of the regression analysis was examined, $\mathrm{F}$ statistic was found significant $(p=.000 ; F=36.94)$. Therefore, the model in which firm performance was explained with TMC was significant. The proposed model is as follows;

$$
y=1.916+0.480 x
$$

In the model, $y$ represents performance, and $x$ stands for TMC (Firm performance $=1.916+0.480 x T M C$ ) According to the model, 1 unit change in TMC causes an increase of 0.480 units in performance. Since the t value related to the coefficient was significant $(p=.00)$, the coefficient of the TMC variable was found statistically significant. Therefore, $\mathrm{H}_{2}$ suggesting that the firm performance will be affected by the level of technology management capability was supported by the findings.

\subsubsection{Investigation of Firm Performance by Strategy Type}

One-way ANOVA was used to examine whether the organizations' performances differ according to the strategy type. Levene's test outputs showed that the variances were homogeneous $(p=.522>.05)$. As a result of variance analysis, firm performance varied significantly $(F=4.68 ; p=.004<.05)$ according to firm strategy type. In order to explain what type of strategy this difference stems from, the results of the complementary Tukey HSD test post-hoc tests were examined.

Table 12: Average of firm performance according to strategy types

\begin{tabular}{|l|l|c|c|c|c|c|}
\hline & Group & N & Mean & sd. & F & $p$ \\
\hline \multirow{4}{*}{ Strategy Type } & Prospector & 8 & 3.99 & 0.462 & & \\
\cline { 2 - 7 } & Defender & 14 & 3.24 & 0.596 & 4.68 & $.004^{*}$ \\
\cline { 2 - 7 } & Analyser & 36 & 3.90 & 0.544 & & \\
\cline { 2 - 7 } & Reactor & 61 & 3.66 & 0.665 & & \\
\hline
\end{tabular}

The multiple comparison findings of the Tukey HSD test, which carries out to examine which strategy types are caused by the difference in firm performance by strategy types, are presented in Table 13. 
Pamukkale Üniversitesi Sosyal Bilimler Enstitüsü Dergisi, Sayı 48, Ocak 2022 E. Ozer, Ü. Ay

Table 13: Firm performance and strategy typology Tukey HSD test multiple comparison chart

\begin{tabular}{|l|l|c|c|c|}
\hline Strategy Type (i) & Strategy Type(j) & $\mathrm{i}-\mathrm{j}$ & $\mathrm{SH}$ & $\mathrm{p}$ \\
\hline \multirow{4}{*}{ Prospector } & Defender & $\mathbf{0 . 7 5 7 0 7 9 *}$ & 0.271148 & .031 \\
& Analyser & 0.090853 & 0.239130 & .981 \\
& Reactor & 0.330875 & 0.230048 & .478 \\
\hline \multirow{4}{*}{ Defender } & Prospector & $-\mathbf{0 . 7 5 7 0 7 9 *}$ & 0.271148 & .031 \\
& Analyser & $-0.66622 \mathbf{6}^{*}$ & 0.192696 & .004 \\
& Reactor & -0.426204 & 0.181303 & .093 \\
\hline \multirow{3}{*}{ Analyser } & Prospector & -0.090853 & 0.239130 & .981 \\
& Defender & $\mathbf{0 . 6 6 6 2 2 6 *}$ & 0.192696 & .004 \\
\hline \multirow{3}{*}{ Reactor } & Reactor & 0.240021 & 0.128580 & .248 \\
& Prospector & -0.330875 & 0.230048 & .478 \\
$* \mathrm{p}<.05$ & Defender & 0.426204 & 0.181303 & .093 \\
& Analyser & -0.240021 & 0.128580 & .248 \\
\hline
\end{tabular}

According to the Tukey HSD test, it was concluded that the groups that made the difference were the prospector and defender and, defender and analyser groups. In line with the findings obtained, it was observed that the performance of firms in the prospector strategy type $(3.99 \pm 0.462)$ was higher than the defenders (3.24 $\pm 0.596)$. When the defenders and analysers were compared, the firm performance of the analysers (3.90 \pm $0.544)$ was relatively high.

ANOVA test results supported the research hypothesis that firm performance differs significantly according to the strategy type. Therefore, $H_{3}$ was also supported. The findings showed that the highest firm performance belonged to firms of prospector strategy type.

\subsubsection{Control Variables}

It was aimed to examine whether the sector and firm size control variables determined in the design of the research, but a comparison of the sector could not be made, as the firms in the sample were not proportionally distributed in sub-sectors. Therefore, only the firm size was evaluated as a control variable. For the firm scale, firms are classified as small, medium and large scale according to their number of employees (Table 14). Since there is a relatively proportional distribution between groups, it was examined whether TMC, strategy type and performance show a significant difference in the scale of firms.

Table 14: Firm size data by number of employees

\begin{tabular}{|l|c|c|c|}
\hline Number of Employees & Firm Size & $\mathrm{n}$ & $\%$ \\
\hline$<50$ & Small & 36 & 30 \\
\hline $50<x<250$ & Medium & 39 & 33 \\
\hline$>250$ & Large & 25 & 21 \\
\hline $\mathrm{n}=96$
\end{tabular}

As a result of a one-way analysis of variance, it was found that TMC did not differ significantly depending on the size of firms $(F=0.645 ; p=.527>.05)$. The results of the variance analysis showed that firm performance differs significantly according to the firm scale ( $F=4.92 ; p=.009)$. A complementary pot-hoc comparison test of Benferroni was performed to statistically identify the group from which the difference originated. And here, it was found that the performances of large-scale firms (3.90 \pm .559$)$ were significantly higher than those of smallscale firms (3.43 \pm .55$)$. Finally, Chi-square statistics and crosstabs findings were evaluated in order to examine the relationship between strategy type and firm size. According to cross-table data, there was no significant relationship between the strategy type of firms and the firm size $(p=.063>.05)$. Although the calculated Pearson Chi-square statistic was 11,956, but less than 5 data fell in 6 cells. Therefore, the assumption of The Chi-square test was not met. 


\section{CONCLUSION}

The main goal of this research was to investigate the impacts of technology management capability and strategy type on firm performance. The results are based on a fieldwork covering 119 manufacturing companies operating in Adana and Mersin provinces, in the south region of Turkey. The questionnaire was conducted with senior and middle level managers or experienced experts representing each company. In the questionnaire form, existing scales -with small adjustments- were used to measure TMC and strategy type. New items have been added to the TMC scale and a change has been made in the measurement level of the expressions of the strategy type scale. The variables used to measure firm performance were adopted from previous studies in the literature with a subjective measurement based on declarations.

The findings of the study showed that TMC had a statistically significant effect on firm performance, supporting the several researchers' studies; Zahra and Covin (1995), Zahra (1996), Bharadwaj (2000), Protogerou (2012), Tunçay and Çilingir (2013), Ünsal (2009) and Ünsal and Çetindamar (2015), Bharadwaj (2000), Nazeer, Rasiah and Furuoka (2021). The results of the analysis indicated that the level of the impact of TMC on performance is not very high $\left(R^{2}=.240\right)$, but this does not shadow the findings of the study. Because the purpose of this study is not to establish a strong model regarding the determinants of performance, but to test the effects of the selected variables on performance.

The findings regarding the relationship between TMC and firm performance indicated that there was a moderate-positive relationship between these two variables. Consequently, it is highlighted that companies will increase their performance as they increase the frequency of performing the activities related to technology management, which is evaluated as TMC.

All four-strategy types defined by Miles and Snow (1978) were encountered in manufacturing companies within the scope of the research. Reactor strategy type, which does not represent a coherent strategy and it achieved lower performance than the other three strategy types (Miles and Snow, 1978; Snow and Hrebiniak, 1980; Smith et al., 1986; Conant et al., 1990), was the most common strategy implemented by the manufacturing companies in the sample $(51.3 \%)$. Considering the large portion of small and medium-sized enterprises represented in the study, it can be inferred that reactive strategies are heavily adopted in order to adapt to rapidly changing environmental conditions. The fact that most of the companies following consistent strategies prefer the analyser strategy. This shows that the manufacturing companies in the region carefully evaluate the opportunities and new investments and implement the strategies that have been proven potentially successful by competitors.

The findings supported that firm performance shows a significant difference according to the strategy type. This result is consistent with Conant et al.'s (1990) findings. The empirical studies in the literature suggest that although the performances of the prospectors, analysers and defenders does not differ significantly from each other, they perform higher than the reactors (Conant et al., 1990). Unlike the literature, it was found in the present study that manufacturing firms in the prospector and analyser strategy types achieved higher performance than the defenders. Another surprising finding was that the performance of firms in the reactor strategy type (Mean=3.664) was found higher than the defenders. As also supported by Snow and Hrebiniak's (1980) and, Naktiyok and Karabey's (2007) studies, this finding may be a result from the low competitiveness of the sector or the structural characteristics of the region. Another reason may be the multiple-selection procedure used when measuring the strategy type might have revealed that the companies in the region did not exhibit a dominant and consistent strategy type. In addition, a significant positive relationship was determined between TMC and the four strategy types. While the analysers' technology management capability level is the highest, defender firms performed the lowest.

Consequently, the findings of the study support that technology management capability and strategy type have statistically significant effects on firm performance. The fact that the technology management capabilities have a significant effect on the firm performance supports one of the main arguments of the research, it shows that the researches in this direction should be developed and continued. 


\section{LIMITATIONS AND RECOMMENDATIONS}

The results of the present study should be evaluated with some limitations. Primarily, the data of all the variables were collected at once and from a single person from each firm. Besides, due to the practical impossibilities of data collection from companies, non-probability sampling methods were used. The research results are based on the data collected from Turkish manufacturing companies from two cities between 2016 and 2017. In practice, to evaluate technology management practices and firm strategies as a process and to examine their impacts on performance would take an observation covering three to four years. In this study, although managers were asked to base a three-year process on evaluating questions, the data was collected and evaluated on a one-off basis. Another constraint is the variables used to measure firm performance. Performance criteria in strategy studies are still a matter of much debate. In determining the performance criteria in the study, the criteria used in the studies that received frequent citations in the literature were used. The fact that variables are measured using a single measurement tool can also be considered as a constraint and future studies are suggested to apply different measurement tools to assess the variables. Only firm size was taken as a control variable. Further studies are recommended to assess more firm differences as control variables.

\section{ACKNOWLEDGEMENT}

This paper is based on a PhD dissertation submitted in December 2017 to the Social Sciences Institute of Çağ University, TURKEY (Higher education system graduation certificate number: B40299254EE22E3).

We would like to express our gratitude to Prof. Dilek ÇETINDAMAR for the advices on developing the research model and we deeply appreciate the contribution of Associate Prof. Solmaz Filiz KARABAĞ on the early draft of this paper.

\section{REFERENCES}

Bharadwaj, A. S. (2000). A resource-based Perspective on Information Technology Capability and Firm Performance: An Empirical Investigation. MIS Quarterly, 169-196.

Cetindamar, D., Phaal, R., and Probert, D. (2009). Understanding Technology Management as a Dynamic Capability: A Framework for Technology Management Activities. Technovation, 29(4), 237-246.

Conant, J. S., Mokwa, M. P., and Varadarajan, P. R. (1990). Strategic Types, Distinctive Marketing Competencies and Organizational Performance: A Multiple Measures-based Study. Strategic Management Journal, 11(5), 365-383.

Dess, G. G. (1987). Consensus on Strategy Formulation and Organizational Performance: Competitors in a Fragmented Industry. Strategic Management Journal, 8(3), 259-277.

Dvir, D., Segev, E., and Shenhar, A. (1993). Technology's Varying Impact on the Success of Strategic Business Units Within the Miles and Snow Typology. Strategic Management Journal, 14(2), 155-161.

Evans, J. D. (1996). Straightforward Statistics for the Behavioral Sciences. Pacific Grove, CA: Brooks/Cole.

Ferreira, J., Coelho, A., \& Moutinho, L. (2020). Dynamic Capabilities, Creativity and Innovation Capability and Their Impact on Competitive Advantage and Firm Performance: The Moderating Role of Entrepreneurial Orientation. Technovation, 92, 102061.

Gibbons, P. T., and O'connor, T. O. N. Y. (2003). Strategic Posture, Technology Strategy and Performance Among Small Firms. Journal of Enterprising Culture, 11(02), 131-146.

Gillespie, D. F., and Mileti, D. S. (1977). Technology and the Study of Organizations: An Overview and Appraisal. Academy of Management Review, 2(1), 7-16.

Gnjidić, V. (2014). Researching the Dynamics of Miles and Snow's Strategic Typology. Management-Journal of Contemporary Management Issues, 19(1), 93-117.

Gregory, M. J. (1995).Technology Management: A Process Approach. Proceedings of the Institution of Mechanical Engineers, 209(5), 347-356

Gudanowska, A. E. (2017). Modern Research Trends within Technology Management in the Light of Selected Publications. Procedia Engineering, 182, 247-254. 


\section{Pamukkale Üniversitesi Sosyal Bilimler Enstitüsü Dergisi, Sayı 48, Ocak 2022 E. Ozer, Ü. Ay}

Gupta, A., Chen, I. J., and Chiang, D. (1997). Determining Organizational Structure Choices in Advanced Manufacturing Technology Management. Omega, 25(5), 511-521.

Hair, J. F., Black, W. C., Babin, B. J., Anderson, R. E., and Tatham, R. L. (2014). Multivariate Data Analysis (Vol. 7). Essex: Pearson New International.

Hambrick, D. C. (1983). High Profit Strategies in Mature Capital Goods Industries: A Contingency Approach.Academy of Management Journal, 26(4), 687-707.

Hansen, G. S., and Wernerfelt, B. (1989). Determinants of Firm Performance: The Relative Importance of Economic and Organizational Factors. Strategic Management Journal, 10(5), 399-411.

Itami, H. and Numagami, T. (1992). Dynamic interaction between strategy and technology. Strategic Management Journal, 13(S2), 119-135.

Lin, F. J. and Lai, C. (2020). Key Factors Affecting Technological Capabilities in Small and Medium-sized Enterprises in Taiwan. International Entrepreneurship and Management Journal, 17, 1-13.

March, J. G. (1991). Exploration and Exploitation in Organizational Learning. Organization Science, 2(1), 71-87.

McCann, J. E. (1991). Patterns of growth, competitive technology, and financial strategies in young ventures. Journal of Business Venturing, 6(3), 189-208.

Meyer, A. D. (1982). Adapting to Environmental jolts. Administrative Science Quarterly, 515-537.

Miles, R. E., and C. C. Snow. (1978) Organizational Strategy, Structure, and Process. New York: McGraw-Hill.

Miles, R. E., Snow, C. C., Meyer, A. D. and Coleman, H. J. (1978). Organizational Strategy, Structure, and Process. Academy of Management Review, 3(3), 546-562.

Morrison, R. D. (2020). Technology Management in Central American Maquilas. Global Journal of Business Disciplines, 4(1), 76.

Naktiyok, A. and Karabey, C. N. (2007). Işletmelerin Maddi Olmayan Kaynaklari ve Çevresel Olumsuzluk Algilari ile Stratejik Yönelimleri Arasindaki Ilişki. Ankara Üniversitesi SBF Dergisi, 62(04), 203-225.

National Research Council. (1987). Management of Technology: The Hidden Competitive Advantage. National Academy Press.

Nazeer, N., Rasiah, R. and Furuoka, F. (2021). Technology Transfer, Technological Capability, Absorptive Capacity and Firm Performance: An Investigation of the Textile and Clothing Firms in Pakistan. Malaysian Journal of Economic Studies, 58(1), 99-124.

Parnell, J., \& Brady, M. (2019). Capabilities, Strategies and Firm Performance in the United Kingdom. Journal of Strategy and Management, 12(1), 153-172.

Pelser, T. G., and Prinsloo, J. J. (2014). Technology Management and the link with Technology Strategy and Company Performance. Journal of Global Business and Technology, 10(2).

Porter, M. E. (1980). Competitive Strategy: Techniques for Analyzing Industries and Competitors. New York: FreePress.

Porter, M. E. (1985). Technology and Competitive Advantage. The Journal of Business Strategy, 5(3), 60.

Powell, T. C. (1992). Organizational Alignment as Competitive Advantage. Strategic Management Journal, 13(2), 119-134.

Powell, T. C., and Dent-Micallef, A. (1997). Information Technology as Competitive Advantage: The Role of Human, Business, and Technology Resources. Strategic Management Journal, 18(5), 375-405.

Price, J. L. (1997). Handbook of organizational measurement. International Journal of Manpower, 18(4/5/6), 305558.

Protogerou, A., Caloghirou, Y., and Lioukas, S. (2011). Dynamic Capabilities and Their Indirect Impact on Firm Performance. Industrial and Corporate Change, dtr049.

Rush, H., Bessant, J. and Hobday, M. (2007). Assessing the Technological Capabilities of Firms: Developing a Policy Tool. R\&D Management, 37(3), 221-236.

Schendel, D., and Hofer, C. W. (Eds.). (1979). Strategic management: A new view of business policy and planning. Little, Brown. 
Segev, E. (1987). Strategy, Strategy Making, and Performance- An Empirical Investigation. Management Science, 33(2), 258-269.

Snow, C. C., and Hrebiniak, L. G. (1980). Strategy, Distinctive Competence, and Organizational Performance. Administrative Science Quarterly, 317-336.

Spanos, Y. E., and Lioukas, S. (2001). An Examination into the Causal Logic of Rent Generation: Contrasting Porter's Competitive Strategy Framework and the Resource-Based Perspective. Strategic Management Journal, 22(10), 907-934.

Tippins, M. J., and Sohi, R. S. (2003). IT Competency and Firm Performance: is Organizational Learning a Missing Link?. Strategic Management Journal, 24(8), 745-761.

Tuncay, A., and Çilingir, F. C. (2013). Technology Management Capability Assessment an Empirical Study in Izmir Turkey for Model Development. European International Journal of Science and Technology, 2(8), 176-187.

Xiao, L., and Dasgupta, S. (2009). The Effects of Dynamic it Capability and Organizational Culture on Firm Performance: An Empirical Study. ICIS 2009 Proceedings, 170.

Ünsal, E. (2009). Dinamik bir Yetenek Olarak Teknoloji Yönetimi: Teknoloji Yönetimi Yeteneği. Savunma Bilimleri Dergisi, 8(2), 167-189.

Unsal, E. (2010). Teknoloji Yönetimi Yeteneği. Unpublished PhD Thesis (in Turkish), Kara Harp Okulu, Ankara, Turkey.

Unsal, E., and Cetindamar, D. (2015). Technology Management Capability: Definition, European International Journal of Science and Technology, 4(2), 181-196.

Venkatraman, N. and Ramanujam, V. (1986). Measurement of Business Performance in Strategy Research: A Comparison of Approaches. Academy of Management Review, 11(4), 801-814.

Wernerfelt, B. (1984). A resource-Based View of the Firm. Strategic Management Journal, 5(2), 171-180.

Wu, F., Yeniyurt, S., Kim, D., ve Cavusgil, S.T. (2006). The Impact of Information Technology on Supply Chain Capabilities and Firm Performance: A Resource-Based View. Industrial Marketing Management, 35(4), 493504. (http://doi.org/10.1016/j.indmarman.2005.05.003)

Zahra, S. A. (1995). Corporate Entrepreneurship and Financial Performance: The Case of Management Leveraged Buyouts. Journal of Business Venturing, 10(3), 225-247.

Zahra, S. A. (1996). Governance, Ownership, and Corporate Entrepreneurship: The Moderating Impact of Industry Technological Opportunities. Academy of Management Journal, 39(6), 1713-1735.

Zahra, S. A., and Covin, J. G. (1993). Business Strategy, Technology Policy and Firm Performance. Strategic Management Journal, 14(6), 451-478.

Zahra, S. A., and Covin, J. G. (1995). Contextual Influences on the Corporate Entrepreneurship-Performance Relationship: A Longitudinal Analysis. Journal of Business Venturing, 10(1), 43-58.

\section{Beyan ve Açıklamalar (Disclosure Statements)}

1. Bu çalışmanın yazarları, araştırma ve yayın etiği ilkelerine uyduklarını kabul etmektedirler (The authors of this article confirm that their work complies with the principles of research and publication ethics).

2. Yazarlar tarafından herhangi bir çıkar çatışması beyan edilmemiştir (No potential conflict of interest was reported by the authors).

3. Bu çalışma, intihal tarama programı kullanılarak intihal taramasından geçirilmiştir (This article was screened for potential plagiarism using a plagiarism screening program). 